\title{
Profil Usaha Industri Susu Kedelai UD. Tiga Bersaudara Di Kecamatan Tikala Kota Manado
}

\author{
Dina Ekawati Hungopa \\ Ribka M. Kumaat \\ Lorraine W. Th. Sondakh
}

\begin{abstract}
ABSRACT
This study aimed to describe the Profile of the Soy Milk Industry Enterprises UD. Three Brothers in Sub-district of Tikala, Manado City, seen from the Organizational Structure, raw material procurement, production costs, marketing and profit. The research was conducted from preparation in June until the completion of the report in September 2016. This research was used primary data and secondary data. The primary data obtained through interviews using questionnaires to the owners of the soy milk industry UD Three Brothers in Sub-district of Tikala, Manado City. Primary data collected has studied and analyzed descriptively and presented in tabular form. The results showed that soy milk UD. Three Brothers is packaged in two packages, namely, bottles and packaging wrap. Soy milk is marketed to five places, namely, Freshmart, Golden, Market Karombasan, X.O and Noodle Medan 88, with the price for one bottle and a pack of Rp. 5000.- respectively. Industrial soy milk UD. Three Brothers survived until today because of their perseverance, patience and entrepreneurial spirit of the industry owners.
\end{abstract}

Keywords: Soy Milk Industry Enterprises, Tikala, Manado City, Organizational Structure, raw material procurement, production costs, marketing and profit.

\begin{abstract}
ABSTRAK
Penelitian ini bertujuan untuk mendeskripsikan profil usaha industri susu kedelai UD. Tiga Bersaudara di Kecamatan Tikala, Kota Manado, dilihat dari Struktur Organisasi, pengadaan bahan baku, biaya produksi, pemasaran dan keuntungan. Penelitian dilaksanakan mulai dari persiapan pada bulan Juni sampai penyusunan laporan pada bulan September 2016. Data yang digunakan adalah data primer yang diperoleh melalui wawancara langsung dengan menggunakan kuesioner kepada pemilik industri susu kedelai UD. Tiga Bersaudara di Kecamatan Tikala, Kota Manado. Penelitian ini menggunakan data primer dan data sekunder. Data primer yang telah dikumpulkan dikaji dan dianalisis secara deskriptif serta disajikan dalam bentuk tabel. Hasil penelitian menunjukan bahwa susu kedelai UD. Tiga Bersaudara dikemas dalam dua kemasan yaitu, kemasan botol dan kemasan bungkus. Susu kedelai dipasarkan ke 5 tempat yaitu, Freshmart, Golden, Pasar Karombasan, X.O dan Mie Medan 88, dengan harga untuk satu botol dan satu bungkus sebesar Rp. 5000. Industri susu kedelai UD. Tiga Bersaudara bisa bertahan sampai saat ini berkat adanya ketekunan, kesabaran serta jiwa wirausaha dari pemilik industri.
\end{abstract}

Kata kunci: usaha industri susu kedelai, Tikala, Kota Manado, Struktur Organisasi, pengadaan bahan baku, biaya produksi, pemasaran dan keuntungan 


\section{PENDAHULUAN}

\section{Latar Belakang}

Kedelai merupakan salah satu jenis kacang-kacangan dan mengandung protein yang cukup tinggi. Karena itu, dibutuhkan sebagai bahan makanan, bahan baku industri dan sebagai makanan ternak. Mengingat manfaat kedelai yang begitu besar, maka produksi kedelai perlu ditingkatkan, baik jumlah maupun mutunya. Agar diperoleh jumlah hasil yang banyak dan bermutu tinggi, pasca panen harus dilakukan secara baik dan benar. Penerapan teknologi untuk meningkatkan produksi telah berkembang dengan pesat. Tetapi belum diimbangi dengan penggunaan teknologi pasca panen secara sempurna. Karena itu, produksi mengalami penurunan mutu dan penyusutan bobot. Masalah pokok yang menyebabkan rendahnya mutu kedelai adalah tingginya presentase biji rusak, kadar air dan kadar kotoran. Dengan penggunaan teknologi pasca panen yang sempurna, diharap produksi bisa memenuhi persyaratan yang telah ditetapkan. Kedelai yang memenuhi syarat tersebut dapat dijual dengan harga yang ditetapkan setiap tahun (Departemen Pertanian, 1985).

Industri pengelolahan hasil pertanian menjadi penting untuk dikembangkan, karena pengelolahan hasil pertaniaan dapat meningkatkan nilai tambah dari suatu produk pertanian, penyerapan tenaga kerja, keterampilan produsen dan pedapatan produsen. Salah satu produk pertanian yang banyak dimanfaatkan sebagai bahan baku suatu industri pegelolahan hasil pertanian. Produk hasil olahan salah satunya adalah susu kedelai (Soekartawi, 1991 dalam Pelealu, 2002).

Di Kota Manado sudah banyak komoditas hasil pertanian yang diolah menjadi bahan makanan, salah satunya adalah kacang kedelai. Umumnya, komoditas pertanian memiliki sifat yang mudah rusak. Maka dari itu, perlu untuk dikonsumsi langsung atau diolah dari bahan mentah menjadi bahan jadi terlebih dahulu. Kacang kedelai tidak hanya diolah menjadi bahan makanan, tapi kacang kedelai juga bisa diolah menjadi minuman seperti susu kedelai.

Susu kedelai merupakan minuman yang bergizi, baik bagi kesehatan tubuh dan tanpa bahan kimia/pengawet, yang terbuat dari kacang kedelai. Proses pengelolahan susu kedelai sangat mudah, hanya dengan teknologi dan peralatan yang sederhana dan tidak perlu memiliki keterampilan khusus, siapa saja bisa melakukannya. Susu kedelai di Kota Manado telah mengalami peningkatan, dapat dilihat dari pemasaran susu kedelai yang dipasarkan di berbagai supermarket, Pasar, Rumah sakit, dengan berbagai merek, kemasan dan dari sumber yang berbeda-beda. Dengan demikian peneliti memutuskan untuk meneliti salah satu produk susu kedelai yaitu, susu kedelai UD. Tiga Bersaudara.

Peneliti tertarik dengan susu kedelai UD. Tiga Bersadara, karena pada saat industri ini mulai beroperasi, industri ini belum memiliki nama usaha serta izin usaha. Awalnya pemilik industri ini adalah orang tua (Alarhum) dari Ibu Beatris Maradesa yang telah beroperasi sejak tahun 1982 dan terus bertahan hingga saat ini. Pada tahun 2000 industri ini diwariskan kepada Ibu Beatris Maradesa dan Bapak Spener Duitan. Pada saat industri ini dikelolah oleh Bapak Spener dan Ibu Beatris, industri ini didaftarkan ke Departemen Kesehatan dan Departemen Perindustrian dan Perdagangan. Pada saat didaftarkan industri ini, Bapak Spener dan Ibu Beatris diminta untuk memberikan nama untuk industri yang mereka kelolah. Nama UD. Tiga Bersaudara dipilih menjadi nama industri mereka, yang berasal dari jumlah anak dari Bapak Spener Duitan dan Ibu Beatris Maradesa. UD. Tiga Bersaudara sekarang telah terdaftar secara resmi di Departemen Kesehatan, Departemen Perindustrian dan Perdagangan.

Berdasarkan penjelasan di atas maka perlu untuk mengetahui bagaimana Profil dari usaha industri susu kedelai UD. Tiga Bersaudara, sehingga diperlukan untuk melakukan penelitian mengenai profil usaha industri susu kedelai UD. Tiga Bersaudara di Kecamatan Tikala, Kota Manado.

\section{Perumusan Masalah}

Berdasarkan latar belakang di atas, maka yang menjadi rumusan masalah adalah bagaimana profil usaha pengelolaan susu kedelai UD. Tiga Bersaudara di Kecamatan Tikala yaitu, mengenai struktur organisasi, 
pengadaan bahan baku, biaya produksi, pemasaran dan keuntungan.

\section{Tujuan Penelitian}

Mendeskripsikan profil usaha industri susu kedelai UD. Tiga Bersaudara di Kecamatan Tikala, Kota Manado, dilihat dari struktur organisasi, pengadaan bahan baku, biaya produksi, pemasaran dan keuntungan.

\section{Manfaat Penelitian}

Penelitian ini bermanfaat untuk memberikan pengetahuan mengenai profil usaha khususnya, usaha industri susu kedelai UD. Tiga Bersaudara, dan diharapkan dapat memberikan informasi kepada pemilik usaha susu kedelai demi meningkatkan usaha ini.

\section{METODOLOGI PENELITIAN}

\section{Waktu dan Tempat Penelitian}

Penelitian ini dilaksanakan pada industri UD. Tiga Bersaudara di Kecamatan Tikala, Kota Manado dengan waktu penelitian selama tiga bulan yaitu sejak bulan Juni sampai dengan bulan September 2016, mulai dari persiapan, pengumpulan data, sampai penyusunan laporan hasil penelitian.

\section{Metode Pengumpulan Data}

Metode pengumpulan data dilakukan dengan menggunakan data primer yang diperoleh melalui wawancara langsung dengan menggunakan kuisioner kepada pemilik industrisusu kedelai UD. Tiga Bersaudara di Kecamatan Tikala, Kota Manado.

\section{Konsep Pengukuran Variabel}

1. Struktur organssi industri UD. Tiga Bersaudara

2. Pengadaan bahan baku yaitu jumlah kedelai yang digunakan $(\mathrm{Kg})$ dan bahan penolong seperti, gula pasir $(\mathrm{Kg})$, air (liter) dan daun pandan (lembar)

3. Biaya produksi susu kedelai UD. Tiga Bersadara yang mencakup biaya tetap dan biaya variable

a. Biaya tetap adalah biaya yang besar kecilnya tidak berpengaruh terhadap jumlah produksi yang dihasilkan. Yang termasuk dalam biaya tetap yaitu, biaya penyusutan yang terdiri atas ember, pisau, loyang, timbangan, tretek, saringan, mesin giling, wajan, dongkrat, kompor gas dan spatula, dan biaya pajak

b. Biaya variabel yaitu, biaya yang diperlukan dalam proses produksi yang mempunyai hubungan langsung degan besarnya poduksi susu kedelai UD. Tiga Bersaudara seperti biaya bahan baku $(\mathrm{Rp})$, biaya tenaga kerja (Rp), biaya listrik (Rp), biaya pengemasan (Rp), biaya transportasi (Rp).

4. Pemasaran yaitu, teknik atau cara penyaluran produk dari produsen ke konsumen

1. Mekanisme pemasaran

2. Lokasi pemasaran

3. Harga jual

4. Jumlah penjualan

5. Keuntungan yaitu, besarnya keuntungan yang diperoleh oleh Industri UD. Tiga Bersaudara (Rp).

\section{Metode Analisis Data}

Analisis data yang digunakan dalam penelitian ini yaitu, analisis data secara deskriptif dengan menggunakan data primer dan data sekunder, di mana data yang dikumpulkan dikaji dan dianalisis secara deskriptif serta disajikan dalam bentuk tabel.

1. Untuk mengetahui besar tingkat penerimaan yang diperoleh dapat menggunakan rumus:

$$
\mathbf{T R}=\mathbf{P} \cdot \mathbf{Q}
$$

Dimana:

$$
\begin{aligned}
& \mathrm{TR}=\text { Total Penerimaan }(\mathrm{Rp}) \\
& \mathrm{P}=\operatorname{Harga} \text { Produk }(\mathrm{Rp}) \\
& \mathrm{Q}=\operatorname{Jumlah} \operatorname{Produk}(\mathrm{Rp})
\end{aligned}
$$

2. Untuk mengetahui nilai penyusutan suatu barang menggunakan rumus:

$$
\mathbf{P}=\frac{\mathbf{N b}-\mathbf{N S}}{\mathbf{N}}
$$

Dimana:

$$
\begin{array}{ll}
\mathrm{Nb} & =\text { Nilai Beli } \\
\mathrm{Ns} & =\text { Nilai Sisa } \\
\mathrm{N} & =\text { Umur Ekonomis (bulan) }
\end{array}
$$


3. Untuk mengetahui besarnya biaya produksi yang digunakan dalamm proses produksi susu kedelai UD. Tiga Bersaudara dapat menggunakan rumus:

$$
\mathrm{TC}=\mathrm{TFC}+\mathrm{TVC}
$$

Dimana:

$\mathrm{TC}=$ Total Biaya $(\mathrm{Rp})$

TFC = Total Biaya Tetap (Rp)

$\mathrm{TVC}=$ Total Biaya Variabel $(\mathrm{Rp})$

4. Untuk mengetahui besar tingkat keuntungan yang diperoleh pemilik industri UD. Tiga Bersaudara dapat menggunakan rumus:

$$
\pi=T R-T C
$$

Dimana:

$\pi=$ Keuntungan $(\mathrm{Rp})$

$\mathrm{TR}=$ Total Penerimaan $(\mathrm{Rp})$

$\mathrm{TC}=$ Total Biaya $(\mathrm{Rp})$

\section{HASIL DAN PEMBAHASAN}

\section{Deskripsi Umum Susu Kedelai UD. Tiga Bersaudara}

Susu kedelai UD. Tiga Bersaudara merupakan salah satu industri rumahan. Industri ini mulai beroperasi sejak tahun 1982 dan bertahan hingga saat ini. Pada saat industri ini mulai beroperasi, industri ini belum memiliki nama usaha serta izin usaha. Awalnya pemilik industri ini adalah orang tua (Alarhum) dari Ibu Beatris Maradesa. Pada tahun 2000 industri ini diwariskan kepada Ibu Beatris Maradesa dan Bapak Spener Duitan. Pada saat industri ini dikelola oleh Bapak Spener dan Ibu Beatris, industri ini didaftarkan ke Departemen Kesehatan dan Departemen Perindustrian dan Perdagangan. Pada saat didaftarkan industri ini, Bapak Spener dan Ibu Beatris diminta untuk memberikan nama untuk industri yang mereka kelolah. Nama UD. Tiga Bersaudara dipilih menjadi nama industri mereka, yang berasal dari jumlah anak dari Bapak Spener Duitan dan Ibu Beatris Maradesa. UD. Tiga Bersaudara sekarang telah terdaftar secara resmi di Departemen Kesehatan RI dengan No:SP.1155/1801/2000. Pada tahun 2008 industri ini, telah terdaftar pada Departemen Perdagangan dan Departemen Perindustriaan dengan No : TDT . 062 / D . 09 / Perindag / Ind /12.00.01/VI/2008. Industri ini berlokasi di Kecamatan Tikala, Kota Manado. UD. Tiga Bersaudara tidak hanya memproduksi susu kedelai, ada juga produk lain yang diproduksi dari UD. Tiga Bersaudara, yaitu Tahu Komplit Spener. Industri ini adalah usaha keluarga, di mana tenaga kerjanya adalah anggota keluarga yang berjumlah dua orang.

Industri susu kedelai UD. Tiga Bersaudara sekarang sudah berumur 16 tahun. Menurut pemilik industri modal yang dipakai dalam industri ini adalah modal sendiri, hingga saat ini industri UD. Tiga Bersaudara belum pernah mendapat bantuan modal dari pihak lain. Proses produksinya, dilakukan di Kecamatan Tikala, Kota Manado. Sedangkan untuk pemasaran susu kedelai dipasarkan di supermarket seperti, Golden, Freshmart pusat dan ada juga yang dipasarkan di pasar Karombasan untuk dikonsumsi. Selain itu, susu kedelai juga dipasarkan di Restoran seperti, di Mie Medan 88, dan X.O untuk dijadikan bumbu tambahan dalam masakan. Industri ini juga selalu diperiksa oleh Badan Pengawasan Obat dan Makanan (BPOM) setiap tiga bulan sekali, sehingga industri ini bisa bertahan dan terus berkembang sampai sekarang walaupun banyak persaingan, di mana banyak produk yang sama dengan merek yang berbeda-beda.

\section{Struktur Organisasi}

Industri ini adalah industri keluarga di mana tenaga kerjanya terdiri dari anggota keluarga. Struktur organisasi UD. Tiga Bersaudara masih sederhana, hanya terdiri dari dua bagian saja yaitu, pimpinan dan tenaga kerja. Berdasarkan hasil penelitian, struktur 
organisasi dalam usaha susu kedelai UD. Tiga Bersaudara dapat dilihat pada gambar 1 .

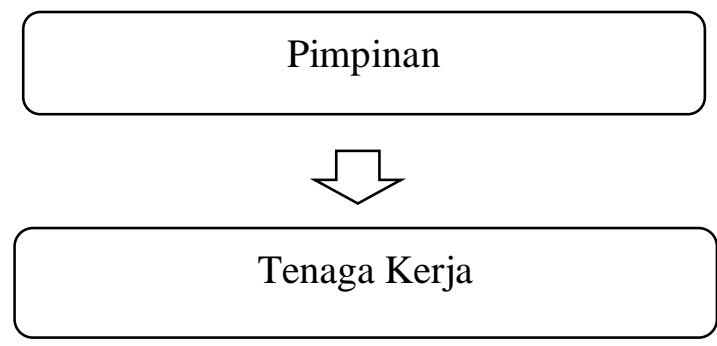

Gambar 1. Struktur Organisasi UD. Tiga Bersaudara

a. Nama Usaha : UD. Tiga Bersaudara

b. Alamat : Kecamatan Tikala, Kota Manado

c. Pemilik : Keluarga Bapak Spener

Duitan dan Ibu Beatris Maradesa

d. Bidang usaha : Susu kedelai UD. Tiga

Bersaudara dan Tahu

Komplit Spener

e. Mulai usaha : 30 Mei, Tahun 2000

f. tenaga kerja : 2 orang (anggota keluarga)

Industri UD. Tiga Bersaudara dikelola langsung oleh anggota keluarga yang menjadi pimpinan, di mana pimpinan tersebut yang mengendalikan semua kegiatan usaha. Pada bagian produksi tugasnya adalah melakukan semua proses produksi yang ada di dalam usaha tersebut, dan tugas tersebut dikerjakan oleh 2 orang yang terdiri dari anggota keluarga. Pemilik industri membuat perencanaan dengan baik dalam usaha ini, di mana bahan baku dan bahan penolong sudah disediakan dari jauh-jauh hari sebelum digunakan, agar tidak kehabisan stok bahan baku dan bahan penolong. Pemilik juga melakukan pengontrolan pada saat proses produksi dimulai sampai akhir. Pengontrolan dilakukan, agar produk yang dihasilkan tidak mengecewakan konsumen.

\section{a. Proses Produksi atau Pengolahan Susu Kedelai UD. Tiga Bersaudara}

Proses produksi yaitu, suatu proses terjadinya perubahan bahan mentah menjadi barang jadi. Proses pengelolahannya, cukup mudah untuk dilakukan dengan tersedianya bahan baku dan bahan penolong yang dibutuhkan berupa kacang kedelai, gula pasir, air dan daun pandan. Berdasarkan hasil penelitian, susu kedelai UD. Tiga Bersaudara diproduksi 6 kali dalam seminggu, sebelum melakukan proses produksi, kacang kedelai dijemur terlebih dahulu sebelum digunakan. Proses produksinya dilakukan pada malam hari, berdasarkan hasil penelitian, pada saat malam hari adalah waktu yang cocok untuk melakukan proses produksi di mana aktivitas yang dilakukan pada malam hari sudah berkurang dibandingkan dengan aktivitas pada siang hari. Proses produksi susu kedelai dari tahap awal hingga tahap akhir adalah sebaga berikut:

Tahap 1. Kacang kedelai direndam selama satu jam

Tahap 2. Kacang kedelai yang sudah direndam kemudian dicuci sampai bersih

Tahap 3. Kacang kedelai yang sudah dicuci kemudian digiling

Tahap 4. Kacang kedelai yang sudah digiling kemudian ditambah dengan air panas

Tahap 5. Kedelai yang sudah ditambahkan air panas kemudian disaring untuk dipisahkan antara santan dengan ampasnya

Tahap 6. Santan yang sudah terpisah dari ampasnya kemudian dimasukkan ke dalam wajan besar untuk dimasak dan ditambahkan daun pandan, kemudian setelah susu kedelai sudah masak ditunggu sampai susu kedelai menjadi dingin

Tahap 7. Susu kedelai yang sudah dingin, kemudian dimasukkan ke dalam kemasan untuk dipasarkan

\section{b. Produksi}

Produksi merupakan kegiatan inti dalam menciptakan bahan mentah menjadi barang jadi. Pengolahan kacang kedelai juga merupakan salah satu proses produksi, di mana bahan baku atau bahan mentah diubah menjadi bahan jadi yang bisa dikonsumsi oleh konsumen. UD. Tiga Bersaudara memproduksi susu kedelai dengan dua jenis kemasan yaitu, kemasan botol dan kemasan bungkus.Tabel 1. dapat dilihat bahwa jumlah produksi untuk periode bulan Juli, untuk kemasan botol yaitu, sebanyak 480 botol. Untuk 
kemasan bungkus sebanyak 672 bungkus. Sedangkan untuk nilai produksi kemasan botol bernilai Rp. 2.400.000. dan kemasan bungkus bernilai Rp. 3.360.000. Harga kemasan untuk botol yaitu, Rp. 5.000 dan kemasan bungkus yaitu, Rp. 5.000. Tabel 1. Dapat dilihat bahwa kemasan bungkus lebih banyak diproduksi. Menurut pemilik industri untuk kemasan botol dan kemasan bungkus harganya disamakan karena volume dalam satu botol dan satu bungkus itu sama yaitu, $600 \mathrm{ml}$.

\section{Penggunaan Bahan Baku dan Bahan Penolong}

\section{a. Bahan Baku}

Bahan baku yang digunakan dalam pembuatan susu kedelai UD. Tiga Bersaudara adalah kacang kedelai. Kacang kedelai yang digunakan diperoleh dari salah satu toko yang berada di Perkamil yang sudah menjadi langganan dari pemilik industri dan kacang kedelai yang biasa digunakan adalah kacang kedelai yang berasal dari Kota Surabaya. Menurut pemilik industri, kacang kedelai yang berasal dari Kota Surabaya memilki kualitas yang sangat bagus. Untuk pembelian kacang kedelai biasanya dilakukan dua minggu sekali sebanyak $60 \mathrm{Kg}$ kacang kedelai untuk pemakaian dua minggu. Untuk penggunaan kacang kedelai dalam satu kali produksi, untuk hari senin sebanyak $11 \mathrm{Kg}$, hari jumat sebanyak $11 \mathrm{Kg}$, untuk hari minggu sebanyak $2 \mathrm{Kg}$, hari selasa sebanyak $2 \mathrm{Kg}$, hari rabu sebanyak $2 \mathrm{Kg}$, hari kamis sebanyak $2 \mathrm{Kg}$, dengan harga per $1 \mathrm{Kg}$ yaitu, $\mathrm{Rp}$. 10.000. Untuk penggunaan kacang kedelai dalam periode bulan Juli 2016 sebanyak 120 Kg dengan biaya Rp. 1.200.000.

\section{b. Bahan Penolong}

Bahan penolong yang digunakan dalam pembuatan susu kedelai adalah Gula pasir, Air, dan daun Pandan.

\section{Gula pasir}

Untuk bahan penolong seperti gula pasir, pemilik industri memperolehnya dari toko-toko terdekat yang ada berada di Tikala. Untuk pembelian gula pasir dilakukan setiap hari, penggunaan gula pasir dalam satu kali produksi, untuk hari senin sebanyak $6 \mathrm{Kg}$, hari jumat sebanyak $6 \mathrm{Kg}$, untuk hari minggu sebanyak $2 \mathrm{Kg}$, hari selasa sebanyak $2 \mathrm{Kg}$, hari rabu sebanyak $2 \mathrm{Kg}$, hari kamis sebanyak $2 \mathrm{Kg}$, dengan harga per $1 \mathrm{Kg}$ yaitu, Rp. 15.000. Untuk penggunaan gula pasir dalam periode bulan Juli 2016 sebanyak $80 \mathrm{Kg}$ dengan biaya $\mathrm{Rp}$. 1.200.000.

\section{Air}

Untuk bahan penolong seperti air, pemilik industri memperolehnya dari sumur mereka sendiri, bila air yang digunakan dalam produksi ini uangkan maka, pemilik industri harus mengeluarkan biaya sebesar Rp. 5.000 per 19 liter. Untuk penggunaan air dalam satu kali produksi, untuk hari senin sebanyak 57 liter, hari jumat sebanyak 57 liter, untuk hari minggu sebanyak 38 liter, hari selasa sebanyak 38 liter, hari rabu sebanyak 38 liter, hari kamis sebanyak 38 liter. Untuk penggunaan air dalam periode bulan Juli 2016 sebanyak 1.064 liter dengan biaya Rp. 280.000 .

\section{Daun Pandan}

Untuk bahan penolong seperti daun pandan, pemilik industri memperolehnya dari halaman rumahnya, bila daun pandan yang digunakan dalam produksi ini uangkan maka, pemilik industri harus mengeluarkan biaya sebesar Rp. 1.000 per 5 lembar. Untuk penggunaan daun pandan dalam satu kali produksi sebanyak 5 lembar. Untuk penggunaan daun pandan dalam periode bulan Juli 2016 sebanyak 120 lembar dengan biaya Rp. 24.000 .

Tabel 2. Menunjukan bahwa penggunaan bahan penolong dalam satu kali produksi setiap harinya berbeda dimana, dalam satu minggu industri ini melakukan proses produksi sebanyak enam kali, di hari senin dan jumat industri ini menggunakan bahan penolong lebih banyak dan menghasilkan susu kedelai juga lebih banyak dibanding hari minggu, selasa, rabu dan kamis. 


\section{Biaya Produksi Susu Kedelai UD. Tiga Bersaudara}

Biaya produksi susu kedelai UD. Tiga Bersaudara merupakan keseluruhan biaya yang dikeluarkan untuk memproduksi susu kedelai. Biaya-biaya yang dikeluarkan untuk memproduksi susu kedelai UD. Tiga Bersaudara adalah sebagai berikut:

\section{a. Biaya Tetap}

1. Biaya Pajak

Biaya pajak industri per bulan yang dikelurkan oleh UD. Tiga Bersaudara adalah sebesar Rp. 25.000, dan pajak per tahunnya yaitu, sebesar Rp. 300.000.

2. Biaya Penyusutan Peralatan

Susu kedelai UD. Tiga Bersaudara dibuat dengan menggunakan beberapa peralatan dan mesin sederhana.Peralatan tersebut terdiri atas ember, loyang, timbangan, tretek, saringan, mesin giling, kompor gas, wajan, dongkrat, spatula. Peralatan-peralatan ini mengalami penyusutan seirng dengan lamanya pemakaian.

Pada Tabel 3. Menunjukan bahwa nilai penyusutan adalah Rp. 148.754,59, penyusutan yang paling besar adalah nilai penyusutan dari wajan dan nilai penyusutan yang paling kecil adalah nilai penyusutan dari tretek.

\section{b. Biaya Variabel}

\section{Biaya Bahan Baku}

Bahan baku memiliki peran penting dalam memproduksi suatu barang atau produk karena tanpabahan baku suatu industri tidak dapat menghasikan sesuatu. Oleh sebab itu, kualitas dari bahan baku menjadi pertimbangan utama dalam pembelian bahan baku. Untuk penggunaan bahan baku selama satu minggu berbeda, untuk hari senin dan jumat lebih banyak menggunakan bahan baku yaitu, sebanyak $11 \mathrm{Kg}$ kacang kedelai setiap hari senin dan jumat, karena di hari senin dan jumat pihak industri harus menyediakan susu kedelai lebih banyak, dan penggunaan bahan baku dihari minggu, selasa, rabu dan kamis, menggunakan bahan baku sebanyak $2 \mathrm{Kg}$ kacang kedelai setiap harinya. Untuk harga kacang kedelai per $1 \mathrm{Kg}$ yaitu, Rp. 10.000.

\section{Biaya bahan Penolong}

Bahan penolong yang digunakan dalam pembuatan susu kedelai adalah Gula pasir, Air, dan daun Pandan.

1. Gula pasir

Untuk penggunaan gula pasir selama satu minggu berbeda, untuk hari senin dan jumat lebih banyak menggunakan gula pasir yaitu, sebanyak $6 \mathrm{Kg}$ di setiap hari senin dan jumat, untuk penggunaan gula pasir di hari minggu, selasa, rabu dan kamis, yaitu sebanyak $2 \mathrm{Kg}$ gula pasir setiap harinya. Untuk harga gula pasir per $1 \mathrm{Kg}$ yaitu, Rp. 15.000

2. Air

Untuk penggunaan air selama satu minggu berbeda, untuk hari senin dan jumat lebih banyak menggunakan air yaitu, sebanyak 57 liter di setiap hari senin dan jumat, untuk penggunaan air di hari minggu, selasa, rabu dan kamis yaitu, sebanyak 38 liter setiap harinya. Untuk harga air per 19 liter yaitu, Rp. 5.000

\section{Daun Pandan}

Untuk penggunaan daun pandan selama satu minggu yaitu, sama untuk hari minggu, senin, selasa, rabu dan kamis dan jumat yaitu, sebanyak 5 lembar setiap harinya. Untuk harga daun pandan per 5 lembar yaitu, Rp. 1.000.

\section{Biaya Tenaga Kerja}

Biaya tenaga kerja pada industri UD. Tiga Bersaudara yaitu, upah yang dikeluarkan untuk membayar tenaga kerja yang berjumlah 2 orang yang terdiri dari anggota keluarga. Biaya tenaga kerja masing-masing diberikan upah sebesar Rp. 62.000 per orang. Total biaya yang dikeluarkan untuk membayar upah 2 orang tenaga kerja dalam satu bulan, dari tahap awal proses pembuatan susu kedelai sampai tahap akhir adalah sebesar Rp. 2.976.000. Di mana dalam satu kali produksi tenaga kerja diberi upah Rp. 62.000 untuk masing-masing tenaga kerja, selama bulan Juli 2016 biaya tenaga kerja dikeluarkan untuk 24 kali produksi.

\section{Biaya Pengemasan}

Biaya pengemasan adalah biaya yang dikeluarkan dalam pembelian perlengkapan seperti botol, plastik, penutup botol dan kertas stempel yang digunakan selama periode bulan Juli 2016. Pada Tabel 4. Menunjukan bahwa biaya perlengkapan yang digunakan dalam 
pengemasan yang terdiri dari botol, plastik, penutup botol dan kertas stempel, harga untuk 1 botol yaitu, Rp. 500. Untuk plastik (bungkus) yaitu, Rp. 4.000 per 1 pak atau per 30 lembar plastik. Untuk harga penutup botol yaitu, Rp. 12.000 per 1 pak atau 50 penutup botol dan untuk kertas stempel yaitu, Rp. 200 per 1 lembar untuk 10 botol.

1. Botol per satuanya Rp. 500. Untuk pemakaian selama satu bulan yaitu, Rp. 240.000

2. Plastik per satu paknya terdapat 30 lembar plastik Rp. 4000. Untuk pemakaian selama satu bulan yaitu, Rp. 89.600

3. Penutup botol per satuannya Rp. 200. Untuk pemakaian satu bulan yaitu, Rp. 115.200

4. Kertas Stempel per 1 lembar 200 untuk 10 botol. Untuk pemakaian satu bulan yaitu, Rp. 9.600.

\section{Biaya Listrik}

Biaya listrik yang dikeluarkan oleh industri dalam proses produksi susu kedelai selama periode bulan Juli 2016 sebesar Rp. 6.240 biaya listrik yang digunakan yaitu, biaya listrik pada lampu, karena dalam proses produksi dibutuhkan lampu untuk menerangi ruangan pada waktu proses produksi selama 5 jam per satu kali produksi.

\section{Biaya Transportasi}

Biaya transportasi yang digunakan dalam industri ini yaitu, pada saat memasarkan susu kedelai ke pedagang pengencer dan konsumen. Untuk transportasi pemilik industri menggunakan sepeda motor miliknya. Pemilik industri memerlukan bahan bakar bensin di pompa bensin, untuk memasarkan susu kedelai dengan harga $\mathrm{Rp}$. 6.500 per 1 liter. Untuk penggunaan bensin dalam satu kali pemasaran sebanyak 1 liter. Untuk penggunaan bensin dalam periode bulan Juli 2016 sebanyak 24 liter dengan biaya Rp. 156.000 .

\section{c. Biaya Total}

Perhitungan total biaya produksi susu kedelai industri UD. Tiga Bersaudara yaitu, meliputi, biaya tetap (penyusutan alat dan biaya pajak) dijumlahkan dengan biaya variabel yang melipui biaya bahan baku, biaya bahan penolong, biaya tenaga kerja, biaya pengemasan, biaya listrik. Untuk lebih jelas dapat dilihat dalam Tabel 5.

\section{Pemasaran Susu Kedelai UD. Tiga Bersaudara}

Pemasaran adalah kegiatan penyaluran Susu kedelai UD. Tiga Bersaudara dari produsen sampai ke konsumen. Penyaluran susu kedelai UD. Tga Bersaudara ada dua yaitu, kepedegan pengecer terlebh dahulu sebelum ke konsumen da nada juga langsung ke konsumen. Untuk penyaluran dilakukan langsung oleh pemilik industri. dan untuk alat transportasi seperti motor yang untuk membantu kelancaran pemasaran susu kedelai UD. Tiga Bersaudara. Susu kedelai yang dihasilkan dalam satu kali produksi setiap harinya berbeda. Untuk hari senin dan jumat industri ini menghasilkan susu kedelai sebanyak 60 botol tiap hari, untuk 30 botol dipasarkan di Freshmart dan 30 botol di Golden, dan 44 bungkus susu kedelai, untuk 20 bungkus dipasarkan di Pasar Karombasan, 12 bungkus di X.O dan 12 bungkus di Mie Medan 88. Jadi jumlah susu kedelai yang dihasilkan di hari senin dan jumat masing sebanyak 104 botol/bungkus.

Untuk hari minggu, selasa, rabu dan kamis industri ini menghasilkan susu kedelai sebanyak 20 bungkus setiap hari, dan dipasarkan ke satu tempat saja yaitu di Pasar Karombasan.

\section{a. Mekanisme pemasaran}

Mekanisme pemasaran produk yaitu, yang pertama saluran pemasaran satu tingkatyaitu, industri "Susu Kedelai UD. Tiga Bersaudara" menjual produknya pada supermarket (Golden, Freshmart pusat, Pasar Karombasan dan Restoran (Mie Medan 88 dan X.O)). 


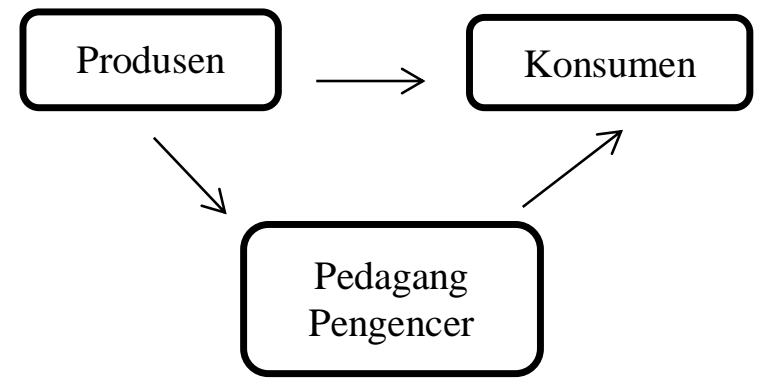

Gambar 3. Saluran pemasaran dalam UD. Tiga Bersaudara

Dapat dilihat pada gambar 3 . Menunjukan saluran pemasaran dalam UD. Tiga Bersaudara, di mana industri UD. Tiga Bersaudara memasarkan produknya ke pedagang pengencer kemudian dijual ke konsumen, dan ada juga yang langsung dipasarkan ke konsumen.Susu kedelai UD. Tiga Bersaudara hanya bertahan selama 3 hari, susu kedelai yang sudah lewat dari 3 hari akan berubah menjadi beku.

\section{b. Lokasi Pemasaran}

Susu kedelai UD. Tiga Bersaudara baru dipasarkan di Kota Manado seperti di Golden, dan Freshmart pusat, Pasar Karombasan serta ada juga di Restoran (Mie Medan 88 dan X.O).

\section{Freshmart}

Untuk pemasaran di Freshmart dilakukan selama satu minggu dua kali. Produk susu kedelai dipasarkan setiap hari senin dan jumat, untuk satu kali pemasaranya sebanyak 30 botol dan kemasan yang dipasarkan yaitu, kemasan botol. Karena kemasan botol merupakan permintaan dan persyaratan dari pihak Freshmart. Untuk sistem pembayaran susu kedelai di Freshmart, yaitu produk dipasarkan terlebih dulu selama tiga hari. Setelah tiga hari dipasarkan, produk akan dibayar sesuai dengan jumlah produk yang telah terjual. Bila terdapat produk susu kedelai yang sudah lewat dari 3 hari tapi belum terjual atau tidak laku maka dari pihak industri akan menarik kembali produk tersebut. Dan jika terdapat produk susu kedelai yang rusak, maka dari pihak industri UD. Tiga Bersaudara akan menggantinya

\section{Golden}

Untuk pemasaran di Golden dilakukan selama satu minggu dua kali. Produk susu kedelai dipasarkan setiap hari senin dan jumat, untuk satu kali pemasaranya sebanyak 30 botol dan kemasan yang dipasarkan yaitu, kemasan botol. Karena kemasan botol merupakan permintaan dan persyaratan dari pihak Golden. Untuk sistem pembayaran susu kedelai di Golden, yaitu produk dipasarkan terlebih dulu selama tiga hari. Setelah tiga hari dipasarkan, produk akan dibayar sesuai dengan jumlah produk yang telah terjual. Bila terdapat produk susu kedelai yang sudah lewat dari 3 hari tapi belum terjual atau tidak laku maka dari pihak industri akan menarik kembali produk tersebut. Dan jika terdapat produk susu kedelai yang rusak, maka dari pihak industri UD. Tiga Bersaudara akan menggantinya

\section{Pasar Karombasan}

Untuk pemasaran di Pasar Karombasan dilakukan selama satu minggu enam kali. Produk susu kedelai dipasarkan setiap hari sebanyak 20 bungkus dan kemasan yang dipasarkan yaitu, kemasan bungkus. Karena kemasan bungkus merupakan kemasan praktis. Untuk sistem pembayaran susu kedelai di Pasar Karombasan, yaitu produk yang telah dipasarkan langsung dibayar oleh konsumen

\section{Restoran X.O}

Untuk pemasaran di Restoran X.O dilakukan selama satu minggu dua kali. Produk susu kedelai dipasarkan setiap hari senin dan jumat, untuk satu kali pemasaranya sebanyak 12 bungkus dan kemasan yang dipasarkan yaitu, kemasan bungkus. Karena kemasan bungkus merupakan permintaan dan persyaratan dari pihak Restoran X.O. Untuk sistem pembayaran susu kedelai di Restoran X.O, yaitu produk yang telah dipasarkan langsung dibayar oleh pihak Restoran

\section{Restoran Mie Medan 88}

Untuk pemasaran di Restoran Mie Medan 88 dilakukan selama satu minggu dua kali. Produk susu kedelai dipasarkan setiap hari senin dan jumat, untuk satu kali pemasaranya 
sebanyak 12 bungkus dan kemasan yang dipasarkan yaitu, kemasan bungkus. Karena kemasan bungkus merupakan permintaan dan persyaratan dari pihak Restoran Mie Medan 88. Untuk sistem pembayaran susu kedelai di Restoran Mie Medan 88, yaitu produk yang telah dipasarkan langsung dibayar oleh pihak Restoran.

\section{c. Harga Jual}

Susu kedelai UD. Tiga Bersaudara dikemas dalam dua jenis kemasan. Untuk harga jual susu kedelai UD. Tiga Bersaudara dalam setiap kemasan yaitu sama.

\section{Kemasan Botol}

Harga untuk susu kedelai dalam per satu botol yaitu, Rp. 5.000. Untuk penjualan susu kedelai dalam kemasan botol selama satu minggu sebanyak 120 botol yaitu, Rp. 600.000

\section{Kemasan Bungkus}

Harga untuk susu kedelai dalam per satu bungkus yaitu, Rp. 5.000. Untuk penjualan susu kedelai dalam kemasan bungkus selama satu minggu sebanyak 168 bungkus yaitu, Rp. 840.000 .

\section{d. Jumlah Penjualan}

Untuk penjualan dalam satu minggu berbeda, untuk hari senin dan jumat industri ini menghasilkan susu kedelai sebanyak 60 botol tiap hari, untuk 30 botol dipasarkan di Freshmart dan 30 botol di Golden, dan 44 bungkus susu kedelai, untuk 20 bungkus dipasarkan di Pasar Karombasan, 12 bungkus X.O dan 12 bungkus Mie Medan 88. Jadi jumlah susu kedelai yang dihasilkan di hari senin dan jumat masing-masing sebanyak 104 botol/bungkus. Untuk hari minggu, selasa, rabu dan kamis industri ini menghasilkan susu kedelai sebanyak 20 bungkus setiap hari dan dipasarkan ke satu tempat saja yaitu di Pasar Karombasan.

\section{Konsep Penerimaan dan Keuntungan}

\section{a. Penerimaan}

Jumlah penerimaan industri UD. Tiga Bersaudara selama bulan Juli 2016, untuk harga per botol dan bungkus Rp. 5.000. Hasil penjualan di Freshmart sebanyak 240 botol yaitu, Rp. 1.200.000. Untuk penjualan di
Golden 240 botol yaitu, Rp. 1.200.000, sedangkan untuk hasil penjualan di pasar Karombasan sebanyak 480 bungkus yaitu, Rp. 2.400.000, dan hasil penjualan untuk 2 Restoran sebanyak 96 bungkus yaitu, Rp. 480.000. Penerimaan merupakan hasil yang diperoleh dari jumlah produksi dikali dengan harga jual. Perhitungan penerimaan dari industri usaha susu kedelai.

$$
\mathbf{T R}=\mathbf{P} . \mathbf{Q}
$$

Dimana:

$$
\begin{array}{ll}
\mathrm{TR} & =\text { Total Penerimaan } \\
\mathrm{P} & =\text { Harga Produk } \\
\mathrm{Q} & =\text { Jumlah Produk }
\end{array}
$$$$
\begin{aligned}
\text { Kemasan botol } & =\text { Rp. } 5.000 \times 480 \\
& =\text { Rp. } 2.400 .000 \\
\text { Kemasan bungkus } & =\text { Rp. } 5.000 \times 672 \\
& =\text { Rp. } 3.360 .000 \\
\text { Total penerimaan } & =\text { Rp. } 5.760 .000
\end{aligned}
$$

\section{b. Keuntungan}

Keuntungan industri susu kedelai UD. Tiga Bersaudara selama bulan Juli 2016, untuk 24 kali produksi sebesar Rp. 5.760.000. Untuk satu kali produksi sebesar Rp. 240.000 (240.000 x 24 kali produksi).

$$
\begin{aligned}
& \text { r } \begin{array}{l}
\boldsymbol{T} \boldsymbol{R}-\boldsymbol{T C} \\
\text { Dimana: } \\
\pi \quad=\text { Keuntungan } \\
\mathrm{TR}=\text { Total Penerimaan } \\
\mathrm{TC}=\text { Total Biaya }
\end{array}
\end{aligned}
$$

Total Penerimaan - Total Biaya

$=$ Rp. $5.760 .000-$ Rp. $6.470 .394,59$

$=$ Rp. $-710.394,59$

Dari hasil yang diperoleh dapat dilihat bahwa indstri UD. Tiga Bersaudara mengalami kerugian sebesar, Rp. -710.394,59 jika industri UD. Tiga Bersaudara menggunakan tenaga kerja dari luar. Apabila tenaga kerja yang digunakan merupakan tenaga kerja keluarga maka industri UD. Tiga Bersaudara tidak mengeluarkan biaya tenaga kerja, dan industri UD. Tiga Bersaudara memperoleh keuntungan sebesar, Rp. 2.265.605,41. Keuntungan ini dipengaruhi oleh jumlah produksi susu kedelai dan biaya yang dikeluarkan. 


\section{KESIMPULAN DAN SARAN}

\section{Kesimpulan}

Melalui hasil penelitan pada industri UD. Tiga Bersaudara di Kecamatan Tikala Kota Manado dapat disimpulkan bahwa Industri UD. Tiga Bersaudara merupakan usaha keluarga, di mana industri ini dikelolah langsung oleh pemilik dan dibantu oleh anggota keluarganya, bahan baku yang digunakan dalam produksi susu kedelai UD. Tiga Bersaudara yaitu, kacang kedelai, biaya produksi dalam industri UD. Tiga Bersaudara selama periode bulan Juli 2016 yaitu, sebesar, Rp. 6.470.394,59 jika menggunakan tenaga kerja dari luar, apabila industri UD. Tiga Bersaudara menggunakan tenaga kerja keluarga maka industri UD. Tiga Bersaudara tidak mengeluarkan biaya tenaga kerja, dan biaya produksi selama periode bulan Juli 2016 sebesar, Rp. 3.494.394,59. Pemasaran produk susu kedelai UD. Tiga Bersaudara masih belum begitu luas, di mana pemasarannya baru di beberapa tempat saja seperti, di Freshmart pusat, Golden, Pasar Karombasan, Mie Medan 88, X.O. Keuntungan yang diperoleh industri UD. Tiga Bersaudara jika menggunakan tenaga kerja keluarga sebesar, Rp. 2.265.605,41. Apabila industry UD. Tiga Bersaudara menggunakan tenaga kerja dari luar, industri UD. Tiga Bersaudara mengalami kerugian sebesar, Rp. - -710.394,59

\section{Saran}

Berdasarkan penelitian yang telah dilakukan, maka saran yang dapat diberikan kepada UD. Tiga Bersaudara yaitu:

1. Perlu mencantumkan tanggal kadaluarsa

2. Perlu adanya pembukuan bulanan dalam Industri UD. Tiga Bersaudara

3. Perlu diperluas lagi pemasaran susu kedelai agar masyarakat lebih mengetahui produk ini

4. Perlu adanya perubahan pada kemasan, agar meningkatkan daya beli konsumen.

\section{DAFTAR PUSTAKA}

Adam. 2006. Profil Industri Kecil "U.D. Putri" di Kelurahan Wangurer Timur Kecamatan Bitung Tengah. Manado. Fakultas Pertanian Jurusan Sosial Ekonomi UNSRAT.

Budi, A, Tim Ricardo. 2004. Penuntun Pengolahan Kedelai. Ricardo. Jakarta.

Feriyanto. 2015. Pengantar Manajemen (3 In 1) Untuk Mahasiswa dan Umum. Mediatera. Yogyakarta.

Jati dan Priyambodo. 2015. Kewirausahaan "Technopreneurship" Untuk Mahasiswa Ilmu-ilmu Eksakta. CV Andi Offset. Yogyakarta

Kumontoy. 2013. Profil Usaha Manisan Pala "Komo Jaya" di Kelurahan Lawangirung Kecamatan Wenang. Manado. Fakultas Pertanian Jurusan Sosial Ekonomi UNSRAT.

Manalu. 2002. Profil Industri Rumah Tangga Anyaman Bambu di Desa Kinilo Kecamatan Tomohon Utara. Manado. Fakultas Pertanian Jurusan Sosial Ekonomi UNSRAT.

Palealu. 2002. Profil Indsutri Rumah Tangga Selai Durian (Dompo) di Kabupaten Tolitoli Provinsi Sulawesi Tengah. Manado. Fakultas Pertanian Jurusan Sosial Ekonomi UNSRAT.

Palealu. 2013. Profil Usaha Minyak Atsiri Pala UD. Widia Mandiri di Desa Treman. Manado. Fakultas Pertanian Jurusan Sosial Ekonomi UNSRAT.

Pandean. 2015. Profil Usaha Industri Pengelolahan Bawang Goreng "Garuda Jaya" CV. Duta Agro Lestari Di Kelurahan Birobuli Kecamatan Palu Selatan Kota Palu. Manado. Fakultas Pertanian Jurusan Sosial Ekonomi UNSRAT. 
Radiyati. 1992. Pengolahan Kedelai. Subang: 1 ; BPTTG Puslitbang

Turnip. 2015. Profil Usaha Agroindustri Susu Kedelai Resoya di Kecamatan Malalayang. Manado. Fakultas Pertanian UNSRAT.
Zulkarnain. 2014. "Entrepeneurial Marketing" Teori dan Implementasi. Graha Ilmu. Yogyakarta. Budi, A, Tim Ricardo, 2004. Penuntun Pengolahan Kedelai. Ricardo. Jakarta. 